\title{
Value Chain Analysis of Indian Edible Mushrooms
}

\author{
C Ganeshkumar ${ }^{1 *}$, M. Prabhu², Sai Prahlada Reddy ${ }^{3}$, Arokiaraj David ${ }^{4}$ \\ ${ }^{1}$ Assistant Professor, Indian Institute of Plantation Management, Bangalore, India and Corresponding author \\ ${ }^{2}$ Assistant Professor, Department of Business Administration, Lebanese French University, Erbil, Kurdistan \\ Region, Iraq \\ ${ }^{3}$ Agribusiness and Plantation Management, Indian Institute of Plantation Management, Bangalore, India \\ ${ }^{4}$ Assistant Professor, Jain University, Bangalore, India
}

\begin{abstract}
The purpose of this study is to examine the value chain analysis of, consumers' awareness level of, and buying motives toward mushroom products. The primary data were collected through face-to-face interviews and by using a questionnaire filled out by 70 consumers from various major mushroom production districts, selected by non-random sampling. Secondary data were collected from various sources. Based on the data analysis, it was found that around $73 \%$ of consumers preferred to buy their mushroom products in the supermarket, and $71 \%$ of consumers responded that factors other than the shape, color, and size of mushrooms motivated them to buy them. The research concludes that urban consumers were well aware of the nutrition value of mushrooms, but their consumption level was very low compared to non-vegetarians urban consumer in the studied area. Nearly $30 \%$ of respondents believed a myth about mushrooms having a mold and were prepared from compost, which causes a bad smell. It was found that that while producers put forth more effort and energy than other actors into the mushroom value chain they received less revenue and profit than wholesalers and retailers. Therefore, policy makers should develop new norms to remove barriers and others issues to safeguard mushroom producers for sustainable growth of the mushroom sector in India. In the future, there will be an increase in the consumption of processed foods. Hence, food companies have to concentrate on mushroom processing and fresh mushroom production.
\end{abstract}

Keywords: Buying motives; Mushrooms; Value chain analysis

\section{Introduction}

Mushrooms are fungal growth that typically take the form of a domed cap on a stalk with gills on the underside of the cap. The cultivation of mushrooms is an emerging industry in many developing countries, such as China, South Africa, Niger, Uganda, Rwanda, and Kenya. Today China is leading mushroom producers in the world both in edible and nonedible types of mushrooms. It accounts for $70 \%$ of world mushroom production, and mushrooms are the sixth-most economically important crop for their country's revenue generation. At present, $96 \%$ of global mushroom production is done by Europeans, Americans, and East Asian countries. Globally, there is a huge demand for mushrooms, which requires more mushroom cultivation. They are mainly cultivated in hilly regions as they require a low temperature to grow (Zhang, 2019). However, technological advancement in modern mushroom cultivation has made it possible to cultivate

${ }^{*}$ Corresponding author's email: gcganeshkumar@gmail.com, Tel.: +91-9986485061 doi: 10.14716/ijtech.v11i3.3979 
mushrooms year-round under certain environmental conditions. In the last decade, large numbers of commercials units have been built by entrepreneurs and farmers throughout the India for the production of button mushrooms. However, there are some practical difficulties, such as $90 \%$ of moisture content in mushrooms quickly vanishing and surprising deterioration immediately after harvest. As they are highly perishable, fresh mushrooms are processed to extend their shelf-life (Berawi, 2019). During the off-season it is an appropriate use of post-harvest technology to process surplus mushrooms into novel value-added products that will add product value.

In spite of all the major constraints faced by the mushroom industry, the current Indian scenario is quite encouraging, with an overall increase in production of five to six times. However, this is very small quantity if the vast market potential of this large country is to be fully exploited. The mushroom industry has a bright future in India, chiefly because of a large quantity of agro-by-products and agro-waste generated as well as the availability of a large and cheap labor force (Yusuf and Zava, 2019). The table below shows the total area of mushroom cultivated in India and production statistics in metric tons.

Table 1 Area and production of mushrooms in India

\begin{tabular}{lccccc}
\hline Mushrooms & $2014-15$ & $2015-16$ & $2016-17$ & $2017-18$ & $2018-19$ \\
\hline Area & $\mathrm{Na}$ & 170 & 183 & 198 & 230 \\
Production & 51 & 436 & 459 & 487 & 503 \\
\hline
\end{tabular}

Noted: The area is in thousand ha; production is in thousand $\mathrm{mt}$

Source: National Horticulture Board, 2018-2019

In india there are five types of mushrooms produced: white button mushrooms, oyster mushrooms, paddy straw mushrooms, shitake mushrooms, and milky mushrooms. Out of these, the main three types - white button, oyster, and milky mushrooms - are very popular and comprise $90 \%$ of production in india. India consumes 1000 tons of mushrooms per year. An increase in purchasing power has changed the taste and preference of consumers, which help the mushroom market growth (Wakchaure et al., 2011a). Mushrooms are a high-value niche product with great potential to contribute to poverty reduction by properly utilizing agricultural wastes (Yu et al., 2009). Properly disposed waste materials can be converted into compost for the betterment of efficient agricultural processes (Sharma et al., 1997). Mushroom producers had difficulties getting compost due to limited markets available in their locality (Sudhakar et al., 2017). Although it is inexpensive to produce mushrooms in major production areas, the farmers and mushroom companies have struggled to identify the product value to fulfill the needs and wants of consumers (Karthick and Hamsalakshmi, 2017).

\section{Review of Literature}

Mushrooms contain fiber, rich proteins, folic acid, bioactive compounds, ergothioneine, psilocybin, osteoporosis, beta-glucans, and glutathione and are commonly known as a highly nutritious food among vegetarians (Beelman et al., 2003; Lakhanpal and Rana, 2005). There are a lot of benefits from consuming mushrooms regularly, including preventing neurodegenerative diseases such as Alzheimer's and dementia. They contain bioactive components that help to improve brain function, such as cognitive activities (Feeney et al., 2014). They are a healthy food that contains vitamins C, D, E, B12, B2, and B1 and rare minerals like selenium and zinc. They serve as medicine in many developed countries by curing prostate cancer and psychological problems (Feeney et al., 2014). A single dose of psilocybin had significant improvements in reducing anxiety and stress levels. A study 
conducted by Zhang et al. (2019) in 1994 tested 36,499 cancer patients aged between 40 and 79 years old. The study also checked the patients' lifestyle choices, like smoking, drinking habits, physical activities, food consumption patterns, and medical history. The study results show that those who consumed mushrooms once a week reduced prostate cancer by $8 \%$, whereas consuming them more than three times a week reduced it by $17 \%$.

On average, around 50 million people globally are affected by depression and stressrelated problems (Feeney et al., 2014). There are methods and techniques to overcome these problems. Psilocybin can reduce depression and stress and improves mental wellbeing. However, $30 \%$ of depressed people are not taking any kind of drugs or medication, which is a major reason for criminal and violent activities (Siddhartha et al., 2019; Thyagarajan et al., 2019). The psilocybin present in mushrooms can help to improve psychological fitness. It is widely used in North American and European countries, whereas in India, there are many government food guidelines for mushrooms usage among Indian consumers.

According to Wakchaure et al (2011b), the Indian mushroom industry has focused on fresh mushrooms rather than value addition; as a result, losses have occurred in the mushroom industry. At present, its focus is on value-added products rather than fresh produce, due to its low-shelf life and changing consumer consumption patterns. Effective processing techniques will not only increase shelf life but also help increase profits to the companies and processors (Nambirajan and Prabhu, 2010). At present, value-added products in the Indian mushroom industry are available in the form of powder and pickles. The marketing of fresh mushrooms would determine the future industry in India.

In India, value-added mushrooms represent approximately $7 \%$ of the market, which is low when compared to other developing countries. The India per capita consumption of mushrooms is 40 grams, which is also low when compared to America and European countries $(2-3 \mathrm{~kg})$. Indian consumers are not well aware of the medicinal value and nutritional benefits of mushrooms (Chang and Wasser, 2012). Thakur and Singh (2014) described the requirements for mushroom cultivation in India. Their study indicated that around 600 million tons of agricultural waste was produced in a year and the majority of it was left to decompose. This agricultural waste was effectively utilized for mushroom cultivation. It reduced manure expenses and created organic manure for crop plants (David and Ravi, 2017). There are a lot of innovative techniques and production technologies that improve mushroom production (Arumuganathan et al., 2004). Another important problem is price fluctuation. To minimize the price fluctuation during the peak and off season, producers and processors desire to preserve mushrooms for a long period and to extend their shelf-life. The simple techniques to preserve them for longer are drying and precooling. Some other preservation techniques that are helpful are canning, blanching, filling, clinching, exhausting, sterilization, cooling, labeling, and pickling (Devi et al., 2015). To attain higher profits and to maintain international markets, companies have to follow the techniques that are preferred by the consumer. The objective of this study is to examine the functions and constraints in the value chain and to find out consumers' awareness and buying motives toward mushroom products.

\section{Methods}

A structured questionnaire was built based on the reviewed literature. The questionnaire focused on the objectives of the study. Descriptive research was conducted to explore consumer preferences and buying motives. This study was focused on the larger production capacity of mushroom companies in the Andhra Pradesh and Telangana regions. The data was collected from Kurnool, Hyderabad, Jangareddygudem, Nellore, and 
Bangalore districts, major mushroom production units in the above-mentioned regions, which supply white button mushrooms. The sample size was limited to 70 consumers selected by the non-random sampling method. The data were collected through face-to-face interviews with the help of the questionnaire, and secondary data were collected from various sources during November 2019. The statistical software used for data analysis was IBM-SPSS, and the techniques applied were descriptive statistics on frequency tables and inferential statistics, like chi-square tests (Ganeshkumar et al., 2019).

\section{Results and Discussion}

\subsection{Demographic Profile of Mushroom Buyers and its Interpretation}

The data were collected mostly from male consumers $(71 \%)$. The respondents were mainly between 21 and 27 years old (73\%), and 51\% held a post-graduate degree. 45\% of their income was less than ₹50,000 per month. Most of the consumers (81\%) were well aware of mushroom value-added product features, and $67 \%$ were aware of their nutrition value. The more mushroom varieties were not available in the local market (61\%). Around $73 \%$ of consumers preferred to only buy their mushroom products in the supermarket, and $71 \%$ responded that factors other than the shape, color, and size of a mushroom motivated them to buy it, per the buying motives (Arokiaraj et al., 2020) mentioned in the below table.

Table 2 Demographic profile of mushroom users

\begin{tabular}{|c|c|c|c|}
\hline \multicolumn{2}{|c|}{ Profile of Mushroom Users } & \multirow{2}{*}{$\frac{\text { Frequency }}{50}$} & \multirow{2}{*}{$\frac{\text { \% of Respondents }}{71.4}$} \\
\hline Cender & Male & & \\
\hline Gender & Female & 20 & 28.6 \\
\hline \multirow{4}{*}{ Age } & Less than 20 years old & 07 & 10.0 \\
\hline & 21-27 years old & 51 & 72.9 \\
\hline & 28-35 years old & 06 & 08.6 \\
\hline & More than 36 years old & 06 & 08.6 \\
\hline \multirow{2}{*}{ Educational qualification } & Undergraduate & 36 & 51.4 \\
\hline & Post-graduate & 34 & 48.6 \\
\hline \multirow{4}{*}{ Annual income (rupees) } & Less than 50,000 & 32 & 45.7 \\
\hline & $50,000-2$ lakhs & 13 & 18.6 \\
\hline & 2 lakhs-5 lakhs & 12 & 17.1 \\
\hline & More than 5 lakhs & 13 & 18.6 \\
\hline \multirow{2}{*}{$\begin{array}{l}\text { Awareness level of mushrooms \& } \\
\text { value-added mushroom products }\end{array}$} & Yes & 57 & 81.4 \\
\hline & No & 13 & 18.6 \\
\hline \multirow{2}{*}{$\begin{array}{l}\text { Awareness of the nutritive value of } \\
\text { mushrooms }\end{array}$} & Yes & 47 & 67.1 \\
\hline & No & 23 & 32.9 \\
\hline \multirow[b]{2}{*}{ Availability of mushrooms } & Yes & 27 & 38.6 \\
\hline & No & 43 & 61.4 \\
\hline \multirow{3}{*}{ Where prefers to buy mushrooms } & Nearby shops & 17 & 24.3 \\
\hline & Supermarkets & 51 & 72.9 \\
\hline & Online & 02 & 02.9 \\
\hline \multirow{4}{*}{ Buying motives } & Color of the mushroom & 13 & 18.6 \\
\hline & Size of the mushroom & 06 & 08.6 \\
\hline & All other factors & 50 & 71.4 \\
\hline & Shape of the mushroom & 01 & 01.4 \\
\hline \multirow{4}{*}{ Where mainly consumes mushroom } & Home & 10 & 14.3 \\
\hline & Hotels/restaurants & 45 & 64.3 \\
\hline & Fast food centers & 08 & 11.4 \\
\hline & Weddings/functions & 07 & 10.0 \\
\hline \multirow{2}{*}{ Frequency of eating mushrooms } & Once a month & 22 & 31.4 \\
\hline & Every 2-4 months & 23 & 32.9 \\
\hline
\end{tabular}




\begin{tabular}{llcc}
\hline \multicolumn{2}{c}{ Profile of Mushroom Users } & Frequency & \% of Respondents \\
\hline & Every 5-9 months & 15 & 21.4 \\
& Once a year & 10 & 14.3 \\
\hline \multirow{4}{*}{ Value-added mushroom product } & Mushroom papad & 02 & 02.9 \\
you taste frequently & In pickles & 05 & 07.1 \\
& Noodles & 23 & 32.9 \\
& Soup & 07 & 10.0 \\
& None of these & 33 & 47.1 \\
\hline Value-added mushroom product & Yes & 52 & 74.3 \\
available in your area & No & 18 & 25.7 \\
\hline \multirow{3}{*}{ Myths about mushrooms } & Prepared from compost & 29 & 41.4 \\
& Poisonous & 13 & 18.6 \\
& It has a fungus or mold & 28 & 40.0 \\
\hline
\end{tabular}

Source: Authors compiled from primary data, 1 Lakhs $=0.1$ Million

The consumers were asked about where they preferred to eat mushrooms. $63 \%$ of consumers liked to eat them in hotels and restaurants. Around 33\% of consumers consumed mushrooms every 2 to 4 months, and 31\% consumed them once a month. Opinions on the mushroom taste in value-added products were collected from consumers; $47 \%$ of respondents preferred mushroom soup and $33 \%$ noodles. Also, checking the availability of value-added mushroom products in their area, 74\% said they were available in their area. Finally, beliefs about myths about mushrooms were documented. 41\% believed that they were cultivated from compost.

A chi-square test was conducted to find out the buying motives. Consumer preferences when buying mushrooms were selected as dependent variables and the remaining variables were selected as independent variables (Woodhead and Berawi, 2020). The test was performed for the above dependent variables separately.

Table 3 Result of Chi-Square Test for buying motives and buying preferences

\begin{tabular}{lccccc}
\hline \multirow{2}{*}{\multicolumn{1}{c}{ Chi-Square Test }} & \multicolumn{2}{c}{ Buying Preferences } & \multicolumn{2}{c}{ Buying Motives } \\
\cline { 2 - 5 } & $\begin{array}{c}\text { Chi- } \\
\text { Square }\end{array}$ & P-Value & Chi-Square & P-Value \\
\hline Gender & 1.640 & .440 & 2.948 & .400 \\
Age & 6.994 & $.042^{* *}$ & 10.45 & $.041^{* *}$ \\
Educational qualification & 0.178 & .915 & 4.626 & .201 \\
Annual income & 7.175 & $.030^{* *}$ & 19.07 & $.025^{* *}$ \\
Awareness level about mushrooms \& value- & 9.643 & $.008^{*}$ & 1.486 & .686 \\
added products & 0.363 & .834 & 1.659 & .646 \\
Awareness of nutritive value of mushrooms & 6.181 & $.047^{* *}$ & 8.123 & $.044^{* *}$ \\
Availability of mushrooms & 15.42 & $.017^{* *}$ & 7.404 & .595 \\
Where mainly consumes mushrooms & 4.796 & .570 & 7.210 & .615 \\
Frequency of eating mushrooms & 7.680 & $.046^{* *}$ & 14.21 & $.029^{* *}$ \\
Value-added mushroom product you taste & & & & \\
frequently & & & & & .136 \\
Value-added mushroom product available in & 1.637 & .441 & & \\
your area & & & & & \\
\hline
\end{tabular}

Source: Authors compiled from primary data

$>.01$ is *, > .05 is **, > .10 is ***

The test results show that there was a significant association between the dependent variables and age, annual income, awareness level of mushrooms and value-added 
products, availability of mushrooms, where mainly consumes mushrooms, and value-added mushroom products you taste frequently, and the remaining variables were found to be statistically insignificant.

Table 4 Mean rank for mushrooms usages

\begin{tabular}{lccc}
\hline \multicolumn{1}{c}{ Value-added mushrooms } & Mean & Std. Deviation & Rank \\
\hline Mushroom Curry & 2.74 & 0.557 & 1 \\
Mushroom Soup & 2.11 & 0.753 & 2 \\
Mushroom Noodles & 2.07 & 0.767 & 3 \\
Mushroom Biryani & 2.00 & 0.799 & 4 \\
Mushroom Pizza & 1.96 & 0.788 & 5 \\
\hline
\end{tabular}

Source: Authors compiled from primary data

The above table explains the mushroom dishes ordered by the consumers. The dishes were ranked based on the above mean score. The consumers had a high preference for mushroom curry (2.74), ranked number one, followed by mushroom soup (2.11), mushroom noodles (2.07), mushroom biryani (2.00), and mushroom pizza (1.96).

\subsection{Value Chain Analysis for Mushrooms in India}

Mushroom market channels are classified below-channel 1 to 3 from producers to the consumers, directly and indirectly. The value chain analysis for mushroom production in India is explained in the below table.

Mushrooms market channels:

Channel 1 - Producers - Consumers

Channel 2 - Producers - Dealers - Hotels/Restaurants - Consumers

Channel 3 - Producers - Dealers - Retailers - Consumers

Table 5 Distribution of costs and revenues in the market channel

\begin{tabular}{lccccc}
\hline \multirow{2}{*}{ Player } & Purchase & Internal & \multirow{2}{*}{ Total } & \multirow{2}{*}{ Revenue } & \multirow{2}{*}{ Profit } \\
\cline { 2 - 3 } & Inputs & Inputs & & & \\
\hline Producer & 61,000 & 50,000 & 111,000 & 140,000 & 29,000 \\
Wholesaler & 140,000 & NA & 140,000 & 175,000 & 35,000 \\
Retailer & 175,000 & NA & 175,000 & 225,000 & 50,000 \\
\hline
\end{tabular}

Source: Author compiled from secondary resources

From the above table, it can be inferred that retailers received more revenue and profit than producers and wholesalers; also note that normally producers put forth more effort and energy than other actors in the mushroom value chain but receive less revenue and profit than wholesalers and retailers, so policy makers should create new norms to remove barriers and others issues to safeguard mushroom producers for sustainable growth of the mushroom sector in India.

When compared to the rural market, consumers can buy their preferred mushrooms in urban areas. Hotels, restaurants, and urban populations are considered the important consumers for mushrooms. In India, the per capita consumption of mushrooms is 30-40 g, which is very low when compared to developed nations' (the USA, Australia, and European and other western countries) average of $2-3 \mathrm{~kg}$. The consumers have different recipes like 
mushroom curry, mushroom masala, mushroom biryani, etc. to prepare in their home (Rishikesh et al., 2016).

\subsection{Cost of Production of Mushrooms per 4.5 Metric Tons in a Month}

The majority of consumers preferred to have mushroom soup compared to other value-added mushroom dishes. Mushroom soup is available with the value-added products in the supermarkets. In supermarkets like More, Reliance Fresh, and Fresh More, there is a demand of $5 \mathrm{~kg}$ a day of fresh button mushrooms.

Table 6 Cost of production per month

\begin{tabular}{lccr}
\hline \multicolumn{1}{c}{ Raw Materials } & Cost per kg $(₹)$ & Monthly requirement & Per Month \\
\hline Spawn & $100^{*}$ & 7.2 tons* & 7.20 .000 \\
Paddy straw & $5^{*}$ & 750 tons* & 37.50 .000 \\
Electricity charges & & & 15.00 .000 \\
Wages & & & 15.00 .000 \\
Employees & & & 8.70 .000 \\
Coco pit/clay & $6^{*}$ & 165 tons* & 9.90 .000 \\
Transportation & $3^{*}$ & 135 tons & 4.05 .000 \\
Overheads & & & 10.00 .000 \\
Maintenance charges & & 300 tons* & 5.00 .000 \\
Chicken manure & $2^{*}$ & 30 tons* & 6.00 .000 \\
Gypsum & & $2250 \mathrm{~kg}^{*}$ & 2.02 .500 \\
Ammonium sulphate & $1300^{*}$ & $1500^{*}$ & 29.25 .000 \\
Urea & $55^{*}$ & & 82.500 \\
\hline Total & & & 1.50 .45 .000 \\
\hline
\end{tabular}

Source: Author compiled from secondary resources; *Secondary data from various sources like website: http://nrcmushroom.org/

Total revenue generated per month $=₹ 1.89 .00 .000 /-$ (Selling to dealers @ ₹ 140/kg)

Net Income

$=1.89 .00 .000-1.50 .45 .000$

$=₹ 38.55 .000$

In Bangalore, around $50 \%$ of mushrooms are sold to 5 -star restaurants and $25 \%$ in 3 star hotels. Furthermore, there is a huge demand in the local market during weddings and festival occasions. Normally in March to June, there is a huge demand for fresh mushrooms for hotels and restaurants due to scarcity of production and supply caused by unfavorable environmental conditions. On average, for every metric ton of mushrooms in the supplychain the producer gets a profit of ₹29,000 per month, the wholesalers ₹35,000, and the retailers ₹50,000. Urban vegetarian's consumers are well aware of the nutritional value of mushrooms, but their consumption level is very low when compared to non-vegetarians of urban consumers. Nearly $30 \%$ of respondents believed a myth that mushroom had a fungus/mold and was prepared from compost, which caused a bad smell. Furthermore, there was no company in India involved in doing any brand promotional activities or advertisements to create awareness about mushroom products (Ghodeswar, 2008)

\section{Conclusions}

In India, around $40 \mathrm{~g}$ per capita of mushrooms are consumed, whereas in the USA, Australian, and Canada people consume 2-3 kg per capita. In India mushrooms, their nutritional benefits and importance are not known among the public. Many mushroom varieties are not available in local markets. Around $73 \%$ of consumers preferred to only 
buy their mushroom products in the supermarket. Seventy-one percent of consumers responded that factors apart from the shape, color, and size of mushrooms motivated them to buy mushrooms. The consumers were asked about where they preferred to eat mushrooms; $63 \%$ liked to eat in hotels and restaurants. Around 33\% of consumers consumed mushrooms every 2 to 4 months, and $31 \%$ consumed them once in a month. The majority of consumers preferred to have mushroom soup when compared to other valueadded mushroom dishes. Companies like ITC have to create more mushroom awareness campaigns and to increase the productivity of mushrooms. Domestic marketing does not pose a problem at present because only small quantities of mushrooms are being traded. As production develops, marketing promotion measures will need to be undertaken to bolster demand. In the future, there will be an increase in the consumption of processed foods. So, food companies have to concentrate on mushroom processing and fresh mushrooms. Therefore, efforts should be made to increase production and to solve future marketing problems through right kind and effective government rules and regulation in India.

\section{References}

Arokiaraj, D., Ramyar, R.A, Ganeshkumar, C., Gomathi Sankar, J., 2020. An Empirical Analysis of Consumer Behaviour towards Organic Food Products Purchase in India. QualityAccess to Success, Volume 21(177), pp. 128-132

Arumuganathan, T., Rai, R.D., Chandrasekar, V., Hemakar, A.K., 2004. Studies on Canning of Button Mushroom, Agaricus bisporus for Improved Quality. Mushroom Research, Volume 12(2), pp. 117-120

Beelman, R.B., Royse, D.J., Chikthimmah, N., 2003. Bioactive Components in Button Mushroom Agaricus bisporus (J. Lge) Imbach (Agaricomycetideae) of Nutritional, Medicinal, and Biological Importance. International Journal of Medicinal Mushrooms, Volume 5(4), pp. 321-327

Berawi, M.A., 2019. The Role of Industry 4.0 in Achieving Sustainable Development Goals. International Journal of Technology, Volume 10(4), pp. 644-647

Chang, S.T., Wasser, S.P., 2012. The Role of Culinary-Medicinal Mushrooms on Human Welfare with a Pyramid Model for Human Health. International Journal of Medicinal Mushrooms, Volume 14(2), pp. 95-134

David, A., Ravi, S., 2017. The Direness of Cultivable Land Spotted on Agricultural: A Special Reference to Rice Production in South India. Abhinav National Monthly Refereed Journal of Research in Commerce \& Management, Volume 6(9), pp. 55-59

Devi, M.P., Bhowmick, N., Bhanusree, M.R., Ghosh, S.K., 2015. Preparation of Value-Added Products through Preservation. In: Value Addition of Horticultural Crops: Recent Trends and Future Directions, Springer, New Delhi, pp. 13-41

Feeney, M.J., Dwyer, J., Hasler-Lewis, C.M., Milner, J.A., Noakes, M., Rowe, S., Wach, M., Beelman, R.B., Caldwell, J., Cantorna, M.T. and Castlebury, L.A., 2014. Mushrooms and Health Summit Proceedings. The Journal of Nutrition, Volume 144(7), pp.1128S-1136S

Ganeshkumar, C., Prabhu, M., Abdullah, N.N., 2019. Business Analytics and Supply Chain Performance: Partial Least Squares-Structural Equation Modeling (PLS-SEM) Approach. International Journal of Management and Business Research, Volume 9(1), pp. 91-96

Ghodeswar, B.M., 2008. Building Brand Identity in Competitive Markets: A Conceptual Model. Journal of Product \& Brand Management, Volume 17(1), pp. 4-12

Karthick, K., Hamsalakshmi, H., 2017. Current Scenario of the Mushroom Industry in India. International Journal of Commerce and Management Research, Volume 3(3), pp. 23-26 
Lakhanpal, T.N., Rana, M., 2005. Medicinal and Nutraceutical Genetic Resources of Mushrooms. Plant Genetic Resources, Volume 3(2), pp. 288-303

Nambirajan, T., Prabhu, M., 2010. Determinants of Competitiveness of Small-scale Industries in Union Territory of Puducherry. Advances in Management, Volume 3(5), pp. 46-49

National Horticulture Board, 2019. Annual Report 2018-2019, Ministry of Agriculture and Farmers Welfare, Government of India

Rishikesh P, Ganeshkumar, C, 2016. Brand Familiarity in Service Sector. International Journal of Applied Business and Economic Research, Volume 14(6), pp. 4077-4086

Sharma, V.K., Canditelli, M., Fortuna, F., Cornacchia, G., 1997. Processing of Urban and AgroIndustrial Residues by Aerobic Composting. Energy Conversion and Management, Volume 38(5), pp. 453-478

Siddhartha, T., Nambirajan, T., Ganeshkumar, C., 2019. Production and Retailing of Self-Help Group Products. Global Business and Economics Review, Volume 21(6), pp. 814-835

Sudhakar, B.D., Kattepogu, N., David, A., 2017. Marketing Assistance and Digital Branding An Insight for Technology Up-Gradation for MSME's. International Journal of Management Studies \& Research, Volume 5(1), pp. 1562-2455

Thakur, M.P., Singh, H.K., 2014. Advances in the Cultivation Technology of Tropical Mushrooms in India. Jawaharlal Nehru Krishi Vishwa Vidyalaya(JNKVV) Research Journal, Volume 48(2), pp. 120-135

Thyagarajan, S., Nambirajan, T., Chandirasekaran, G., 2019. An Empirical Analysis of Training Facilities in Micro-Small-Medium Enterprises (MSME) for Self-Help Groups (SHG). Ushus-Journal of Business Management, Volume 18(2), pp. 23-42

Wakchaure, G.C., 2011a. Postharvest Handling of Fresh Mushrooms. In: Mushrooms: Cultivation, Marketing, and Consumption, Directorate of Mushroom Research, Indian Council of Agricultural Research, Solan, India, pp. 197-206

Wakchaure, G.C., 2011b. Production and Marketing of Mushrooms: Global and National Scenario. In: Mushrooms: Cultivation, Marketing, and Consumption, Directorate of Mushroom Research, Indian Council of Agricultural Research, Solan, India, pp. 15-22

Woodhead, R., Berawi, M.A. 2020. Value Creation and the Pursuit of Multi-Factor Productivity Improvement. International Journal of Technology, Volume 11(1), pp. 111-122

Yu, S., Weaver, V., Martin, K., Cantorna, M.T., 2009. The Effects of Whole Mushrooms during Inflammation. BMC Immunology, Volume 10(1), p. 12

Yusuf, I.T., Zava, A.E., 2019. Investigating the Suitability of Coconut Husk Ash as a Road Soil Stabilizer. International Journal of Technology, Volume 10(1), pp. 27-35

Zhang, S., Sugawara, Y., Chen, S., Beelman, R.B., Tsuduki, T., Tomata, Y., Tsuji, I., 2019. Mushroom Consumption and Incident Risk of Prostate Cancer in Japan: A Pooled Analysis of the Miyagi Cohort Study and the Ohsaki Cohort Study. International Journal of Cancer, Volume 146(10), pp. 2712-2720 